\title{
Investors' stock trading behavior: Perspective of Dhaka Stock Exchange
}

\author{
S.M. Arifuzzaman ${ }^{1}$, Mohammad Noman Hossain Chowdhury, Md. Abdus \\ Shahed \\ ${ }^{1}$ Assistant Professor, Department of Finance, Faculty of Business Administration, American International \\ University-Bangladesh, , \\ ${ }^{2}$ Senior Analyst, Millennium Information Solution Limited, \\ ${ }^{3}$ Lecturer, Department of Finance, Faculty of Business Administration, American International University- \\ Bangladesh
}

\begin{abstract}
When it comes to trading stocks, behavior is often an issue. Being aware of the trading behavior of investors is vital as many stockholders are subject to their behavioral influences. This study uses descriptive statistics to investigate the stock trading behavior of investors of Dhaka Stock Exchange, explore the relationship between demographic characteristics and trading behavior, and examine the difference in trading behavior of stock traders with different demographic characteristics.

Major findings of this research include majority of the traders have an average holding period of less than a month, target for a minimum profit of 0\%-40\% before selling stocks, can tolerate a maximum loss of 0 $40 \%$ before selling their stocks, prefer to the maximum amount of their investment money in the banks and financial institutions, invest more than 50\% of their investment money in the most preferred industry. It also finds some differences in trading behavior if they are categorized by gender, age group and highest educational level.
\end{abstract}

Keywords- trading behavior, Dhaka stock exchange, demographic, gender, age group, highest educational level.

\section{Introduction:}

Capital Market is an important instrument of a country in allocating financial resources in the most efficient manner. Capital market of Bangladesh is still under developed to be a prime mover for the Bangladesh economy. For trading stocks as it happens in the emerging economy, behavior plays a very important role than rationality. The behavioral issues are rooted in the reality that as human beings, people are not completely rational while making trading decisions. In addition, different segments of investors tend to have different trading behavior.

Being aware of the trading behavior of investors is crucial since many stakeholders are subject to their behavioral influences. This study uses descriptive statistics to investigate the stock trading behavior of investors of Dhaka Stock Exchange, explore the relationship between demographic characteristics and trading behavior, and examine the difference in trading behavior of stock traders with different demographic characteristics.

\section{Objectives:}

1. Investigate the stock trading behavior of the investors of Dhaka Stock Exchange

2. Examine the relationship between demographic characteristics and trading behavior of Bangladeshi investors.

3. Explore the differences among the trading behavior of the investors with different demographic characteristics.

\section{Review of Literature:}

This chapter is devoted to literature exploration - a review of researches that are relevant to the study of stock trading behavior of investors with different demographic characteristics.

\section{Gender Differences in Risk Aversion}

A study commissioned by a major brokerage firm found that gender is the third most powerful determinant of investing, after age and income are considered (Bajtelsmith and Bernasek, 1996). There is a significant body of research, both empirical and anecdotal, which supports the position that women are more risk averse than men when they invest. Barber and Odean (1995) surveyed the literature, which indicates that women have different attitudes toward money and investing from men. Barskey et al. (1996) states that women are more risk averse than men, Bruce and Johnson (1994) maintain that men take more investment risks, and Jianakoplos and Barnesek (1998) state that a significantly higher percentage of women than men are unwilling 
to take any financial risk at all. Lewellen et al. (1977) demonstrates that women hold less risky portfolios than men, and that men tilt their portfolios toward higher betas and smaller stocks.

\section{Gender Differences in Confidence}

Closely related to the finding that women are less risk tolerant investors is the finding that women are less confident in their financial decision making. Estes and Hosseini (1988) found that female investors have significantly lower confidence in their investment decisions than male investors even when controlling for background and ability, and when the expected outcomes of the different investments were equivalent.

\section{Impact of Age on Stock Investment}

Papke (1998) found some evidence that investment in stocks declines with age: the coefficient estimate indicates about a 2 percentage-point drop in stock for each additional year of age.

\section{Summary}

The literature review has demonstrated that there is a relationship between the demographic characteristics and trading behavior of investors. The literature review covers several demographic characteristics such as gender and age that have an impact on stock trading behavior.

However, based on my interest in the subject, the scope of my research would also consider one additional demographic characteristic -highest educational level. The responses to the survey would be presented by these demographic characteristics as well, but testing for their statistical significance is beyond the scope of this study.

\section{Methodology:}

Data sources include both primary and secondary sources. Questionnaires are used for securing feedback on trading behavior. Investors were asked several questions relating to their trading behaviors. Respondents were classified by gender, age and the highest educational level. The questionnaire was divided into two sections. The former section of the questionnaire captured the demographic characteristics of the respondents and the latter one captured the trading behavior.

\section{Sample of the Study:}

Questionnaires were given to 250 investors of 5 brokerage houses. We got the responses from 230 investors and out of them 36 were incomplete, so our sample includes 194 investors. The study of trading behavior was based on this sample.

\section{Data and tools:}

Microsoft Excel 2007 was used to analyze the data collected from the questionnaires.

\section{Demographics of Respondents}

\section{Results \& Discussions:}

\subsection{Gender}

Table 1: Distribution of Stock traders by Gender:

\begin{tabular}{|l|l|}
\hline Gender & Percentage \\
\hline Male & $55 \%$ \\
\hline Female & $45 \%$ \\
\hline Total & $100 \%$ \\
\hline
\end{tabular}

1.2 Age

Table2: Distribution of Stock Traders by "Age Group":

\begin{tabular}{|l|l|}
\hline Age & Percentage \\
\hline Less than 25 & 22.22 \\
\hline Between 25 to 35 & 35.16 \\
\hline Between 35-45 & 20.22 \\
\hline Between 45-55 & 14.2 \\
\hline Above 55 & 8.2 \\
\hline
\end{tabular}




\begin{tabular}{|l|l|}
\hline Total & 100 \\
\hline
\end{tabular}

Table 2 indicates that majority of the investors are less than 45 years old.

1.3 Highest Educational Level

Table 3: Distribution of Stock Traders by "Highest Educational Level":

\begin{tabular}{|l|l|l|}
\hline Education Status & Percent & Cumulative \\
\hline Below SSC & 2.6 & 2.6 \\
\hline S.S.C & 4.23 & 6.83 \\
\hline H.S.C & 6.22 & 13.05 \\
\hline Bachelor's Degree & 60.22 & 73.27 \\
\hline Master's Degree & 25.63 & 98.9 \\
\hline PhD. & 2.6 & 100 \\
\hline
\end{tabular}

Table 3; indicates that two dominating investors group are: Bachelors Degree and Masters Degree holders, so when we will discuss on the trading behavior based on highest educational level only investors with Bachelors and Masters Degree holders will be considered.

\section{Trading Behavior of Respondents by Gender}

Table 4: Distribution of Stock Traders by "Gender and Maximum Monetary Amount of Stocks the Portfolio can hold":

\begin{tabular}{|l|l|l|}
\hline \multirow{2}{*}{ Amount (BDT) } & \multicolumn{2}{|c|}{ Percentage } \\
\cline { 2 - 3 } & Male & Female \\
\hline Less than 500,000 & 12.1 & 51.22 \\
\hline $500,000-10,00000$ & 15.33 & 43.77 \\
\hline $10,00000-30,00000$ & 42.33 & 2.32 \\
\hline $30,00000-50,00000$ & 16.25 & 1.47 \\
\hline Above 50,00000 & 13.99 & 1.22 \\
\hline Total & 100 & 100 \\
\hline
\end{tabular}

The result indicates that male traders' investment size more than that of female investors. Majority of the female traders have invested less than 10 Lac whereas majority male traders' investment size is above 10 Lac.

Table 5: Distribution of Stock Traders by "Gender and on average how long investors hold their stocks before selling (Average holding period)"

\begin{tabular}{|l|l|l|}
\hline $\begin{array}{l}\text { Average Holding } \\
\text { Period }\end{array}$ & Percentage \\
\cline { 2 - 3 } & Male & Female \\
\hline Less than a month & 37.5 & 27.2 \\
\hline Between 3 to 6 month & 48.7 & 69.5 \\
\hline Between 6 to 9 month & 0 & 3.3 \\
\hline Between 9 to 12 month & 7.6 & 0 \\
\hline More than 1 year & 6.2 & 0 \\
\hline Total & 100 & 100 \\
\hline
\end{tabular}

Table 5 shows than majority of traders prefer to hold stocks for period less than six months, but the preference tends to be stronger in female traders. For holding period of more than six months, the percentage is higher for male traders. 
Table 6: Distribution of Stock Traders by "Gender and their minimum target profit before selling their stocks (Unrealized gain)"

\begin{tabular}{|l|l|l|}
\hline \multicolumn{1}{|c|}{$\begin{array}{c}\text { Minimum } \\
\text { Target Profit } \\
(\%)\end{array}$} & Male & Female \\
\cline { 2 - 3 } & 43.22 & 66.25 \\
\hline $0-20$ & 38.32 & 32.22 \\
\hline $20-40$ & 11.23 & 1.53 \\
\hline $40-60$ & 5.22 & 0 \\
\hline $60-80$ & 2.01 & 0 \\
\hline $80-100$ & 0 & 0 \\
\hline More than 100 & 100 & 100 \\
\hline Total & & \\
\hline
\end{tabular}

Table 6 indicates that majority of the traders look forward to a minimum of 0\%-40\% profit before selling their stock. Female investors tend to require less minimum target profit than their counterparts as can be seen that at 0\%-20\% profit more female investors are willing to sell their stocks. Very few investors sell their stocks at a profit level higher than $20 \%$.

Table 7: Distribution of Stock Traders by "Gender and amount of loss the investors can tolerate before deciding to sell stocks (Unrealized loss)"

\begin{tabular}{|l|l|l|}
\hline $\begin{array}{l}\text { Maximum } \\
\text { Tolerable Loss } \\
(\%)\end{array}$ & Percentage \\
\cline { 3 - 3 } & Male & Female \\
\hline $0-20$ & 50.22 & 66.25 \\
\hline $20-40$ & 26.22 & 32.75 \\
\hline $40-60$ & 14.11 & 1 \\
\hline $60-80$ & 9.45 & 0 \\
\hline $80-100$ & 0 & 0 \\
\hline More than 100 & 0 & 0 \\
\hline Total & 100 & 100 \\
\hline
\end{tabular}

Table 7 indicates that at loss level less than $40 \%$, female traders tend to be more tolerating to loss, however at above $40 \%$ male traders are more tolerate.

Table 8: Distribution of Stock Traders by "Gender and Industry/ sector where they spend the maximum amount of investments (Please choose one)"

\begin{tabular}{|l|l|l|}
\hline Industry/Sector with & Percentage \\
\cline { 2 - 3 } Maximum Investment & Male & Female \\
& & \\
\hline Bank & 45.22 & 52.22 \\
\hline Financial Institutions & 33.67 & 28.77 \\
\hline Pharmaceuticals & 12.27 & 9.33 \\
\hline Mutual Funds & 5.09 & 2.22 \\
\hline Other & 3.75 & 7.46 \\
\hline Total & 100 & 100 \\
\hline
\end{tabular}

Table 8 indicates that both male and female traders spend the maximum amount of their investment money in the Banks and financial institutions. From the result it can be also found that not much traders are investing a good amount of money in mutual funds. 


\section{Trading Behavior of Respondents by Age}

Table 9: Distribution of Stock Traders by "Age and Maximum Monetary Amount of Stocks the Portfolio can hold"

\begin{tabular}{|l|l|l|l|l|l|}
\hline Amount & \multicolumn{4}{|l|}{ Percentage } & \multicolumn{5}{l|}{} \\
\cline { 2 - 6 } & Less than 25 & $25-35$ & $35-45$ & $45-55$ & More than 55 \\
\hline $\begin{array}{l}\text { Less than } \\
500,000\end{array}$ & 100 & 17.56 & 8.81 & 12.36 & 22.66 \\
\hline $\begin{array}{l}500,000- \\
10,00000\end{array}$ & 0 & 66.22 & 41.22 & 25.22 & 37.12 \\
\hline $\begin{array}{l}10,00000- \\
30,00000\end{array}$ & 0 & 16.22 & 32.21 & 60.22 & 40.22 \\
\hline $\begin{array}{l}30,00000- \\
50,00000\end{array}$ & 0 & 0 & 14.56 & 2.2 & 0 \\
\hline Above 50,00000 & 0 & 0 & 3.2 & 0 & 0 \\
\hline Total & 100 & 100 & 100 & 100 & 100 \\
\hline
\end{tabular}

Age group below 25 prefers to have a maximum portfolio size of less than 5 Lac BDT while only one group (age 35-45) have investment more than 50 Lac BDT.

Table 10: Distribution of Stock Traders by "Age group and on average how long investors hold their stocks before selling (Average holding period)"

\begin{tabular}{|l|l|l|l|l|l|}
\hline $\begin{array}{l}\text { Average Holding } \\
\text { period }\end{array}$ & Percentage \\
\cline { 2 - 6 } & Less than 25 & $25-35$ & $35-45$ & $45-55$ & More than 55 \\
\hline Less than a month & 100 & 30.33 & 40.11 & 12.36 & 22.66 \\
\hline $\begin{array}{l}\text { Between } 3 \text { to } 6 \\
\text { month }\end{array}$ & 0 & 55.2 & 35.22 & 25.22 & 37.12 \\
\hline $\begin{array}{l}\text { Between } 6 \text { to } 9 \\
\text { month }\end{array}$ & 0 & 12.1 & 9.29 & 60.22 & 40.22 \\
\hline $\begin{array}{l}\text { Between } 9 \text { to } 12 \\
\text { month }\end{array}$ & 0 & 2.37 & 9.22 & 2.2 & 0 \\
\hline More than 1 year & 0 & 0 & 6.16 & 0 & 0 \\
\hline Total & 100 & 100 & 100 & 100 & 100 \\
\hline
\end{tabular}

The results demonstrates that majority of traders prefer to hold stocks for period less than six months, but the preference tends to be stronger in younger traders. However, some matured citizens prefer to hold for more than 6 months. This indicates that investors irrespective of their age are very short-sighted.

Table 11: Distribution of Stock Traders by "Age group and their minimum target profit before selling their stocks (Unrealized gain)"

\begin{tabular}{|l|l|l|l|l|l|}
\hline Minimum Target & \multicolumn{5}{|l|}{ Percentage } \\
\cline { 2 - 6 } Profit (\%) & Less than 25 & $25-35$ & $35-45$ & $45-55$ & More than 55 \\
\hline $0-20$ & 20.22 & 40.45 & 40.11 & 67.22 & 90.11 \\
\hline $20-40$ & 42.22 & 38.22 & 35.22 & 22.22 & 6.11 \\
\hline $40-60$ & 21.22 & 18.96 & 9.29 & 8.36 & 3.78 \\
\hline $60-80$ & 16.34 & 2.37 & 9.22 & 2.2 & 0 \\
\hline $80-100$ & 0 & 0 & 6.16 & 0 & 0 \\
\hline Above 100 & 0 & 0 & 0 & 0 & 0 \\
\hline Total & 100 & 100 & 100 & 100 & 100 \\
\hline
\end{tabular}


Table 11; indicates that majority of the traders look forward to a minimum of $0 \%-40 \%$ profit before selling their stock. However, higher level of profit is expected by the younger investors.

Table 12: Distribution of Stock Traders by “Age group and amount of loss the investors can tolerate before deciding to sell stocks (Unrealized loss)"

\begin{tabular}{|c|c|c|c|c|c|}
\hline \multirow{2}{*}{$\begin{array}{c}\text { Minimum } \\
\text { Tolerable Loss } \\
(\%)\end{array}$} & \multicolumn{5}{|l|}{ Percentage } \\
\hline & Less than 25 & $25-35$ & $35-45$ & $45-55$ & More than 55 \\
\hline $0-20$ & 92.22 & 78.56 & 66.23 & 55.22 & 97.2 \\
\hline $20-40$ & 7.78 & 20.22 & 18.56 & 32.11 & 2.8 \\
\hline $40-60$ & 0 & 1.22 & 5.92 & 8.36 & 0 \\
\hline $60-80$ & 0 & 0 & 0 & 4.31 & 0 \\
\hline $80-100$ & 0 & 0 & 0 & 0 & 0 \\
\hline Above 100 & 0 & 0 & 0 & 0 & 0 \\
\hline Total & 100 & 100 & 90.71 & 100 & 100 \\
\hline
\end{tabular}

Table 12; indicates that majority of the traders in all age groups can tolerate a maximum loss of $0 \%-20 \%$ before selling their stocks. However it can be observed that the tolerance level increases with age but again decline for the oldest group.

Table 13: Distribution of Stock Traders by “Age group and Industry/ sector where they spend the maximum amount of investments (Please choose one)"

\begin{tabular}{|c|c|c|c|c|c|}
\hline \multirow{2}{*}{$\begin{array}{l}\text { Industry/Sector } \\
\text { with Maximum } \\
\text { Investment }\end{array}$} & \multicolumn{5}{|l|}{ Percentage } \\
\hline & Less than 25 & $25-35$ & $35-45$ & $45-55$ & More than 55 \\
\hline Bank & 92.22 & 78.56 & 66.23 & 55.22 & 97.2 \\
\hline $\begin{array}{l}\text { Financial } \\
\text { Institutions }\end{array}$ & 7.78 & 20.22 & 18.56 & 32.11 & 2.8 \\
\hline Pharmaceuticals & 0 & 1.22 & 5.92 & 8.36 & 0 \\
\hline Mutual Funds & 0 & 0 & 0 & 4.31 & 0 \\
\hline Other & 0 & 0 & 0 & 0 & 0 \\
\hline Total & 100 & 100 & 90.71 & 100 & 100 \\
\hline
\end{tabular}

Traders of all age group spend the maximum amount of their investment money in the Banks and financial institutions. The result also shows that the younger age group do not spend good amount of money in the mutual funds.

\section{Trading Behavior of Respondents by Highest Educational Level}

Table 14: Distribution of Stock Traders by "Highest Educational Level and Maximum Monetary Amount of Stocks the Portfolio can hold"

\begin{tabular}{|l|l|l|}
\hline \multirow{2}{*}{ Amount } & Percentage \\
\cline { 2 - 3 } & Bachelors & Masters \\
\hline Less than 500,000 & 21.78 & 28.22 \\
\hline $500,000-10,00000$ & 20.22 & 43.77 \\
\hline $10,00000-30,00000$ & 14.2 & 16.11 \\
\hline $30,00000-50,00000$ & 25.6 & 10.2 \\
\hline Above 50,00000 & 18.2 & 1.7 \\
\hline Total & 100 & 100 \\
\hline
\end{tabular}


Table 14; indicates that Bachelors Degree holders' investment size higher than that of Masters Degree holders.

Table 15: Distribution of Stock Traders by "Highest Educational Level and on average how long investors hold their stocks before selling (Average holding period)"

\begin{tabular}{|l|l|l|}
\hline \multirow{2}{*}{ Average Holding Period } & Percentage \\
\cline { 2 - 3 } & Bachelors & Masters \\
\hline Less than a month & 40.22 & 22.2 \\
\hline Between 3 to 6 month & 37.11 & 45.1 \\
\hline Between 6 to 9 month & 12.27 & 18.2 \\
\hline Between 9 to 12 month & 2.2 & 12.2 \\
\hline More than 1 year & 8.2 & 2.3 \\
\hline Total & 100 & 100 \\
\hline
\end{tabular}

Table 15; demonstrates that Bachelor Degree holders prefer to sell their shares earlier than the investors with Masters Degree. Majority of traders prefer to hold stocks for period less than six months, but the preference tends to be stronger in Bachelor Degree holders. For holding period of more than six months, the percentage is higher for Masters Degree holders.

Table 16: Distribution of Stock Traders by "Highest Educational Level and their minimum target profit before selling their stocks (Unrealized gain)"

\begin{tabular}{|l|l|l|}
\hline \multirow{2}{*}{$\begin{array}{l}\text { Minimum Target } \\
\text { Profit }\end{array}$} & \multicolumn{2}{|l|}{ Percentage } \\
\cline { 2 - 3 } & Bachelors & Masters \\
\hline $0-20$ & 40.2 & 70.2 \\
\hline $20-40$ & 35.2 & 27.27 \\
\hline $40-60$ & 16.2 & 2.53 \\
\hline $60-80$ & 5.22 & 0 \\
\hline $80-100$ & 3.18 & 0 \\
\hline More than 100 & 0 & 0 \\
\hline Total & 100 & 100 \\
\hline
\end{tabular}

Table 16; indicates that majority of the traders look forward to a minimum of $0 \%-40 \%$ profit before selling their stock. Masters Degree holders tend to require less minimum target profit than other group as it is observed that at $0 \%-20 \%$ profit more investors are willing to sell their stocks. Very few investors expect to have profit level higher than $40 \%$.

Table 17: Distribution of Stock Traders by "Highest Educational Level and amount of loss the investors can tolerate before deciding to sell stocks (Unrealized loss)"

\begin{tabular}{|l|l|l|}
\hline $\begin{array}{c}\text { Maximum Tolerable } \\
\text { Loss (\%) }\end{array}$ & Percentage \\
\cline { 2 - 3 } & Bachelors & Masters \\
\hline $0-20$ & 65.22 & 48.2 \\
\hline $20-40$ & 33.58 & 22.45 \\
\hline $40-60$ & 1.2 & 18.5 \\
\hline $60-80$ & 0 & 10.85 \\
\hline $80-100$ & 0 & 0 \\
\hline More than 100 & 0 & 0 \\
\hline Total & 100 & 100 \\
\hline
\end{tabular}

The results of this table shows that Masters Degree holders tolerate more risk as good percentage (29.35\%) of them even could tolerate more than $40 \%$ of loss whereas only $1.2 \%$ of Bachelor Degree holders can tolerate that level of risk. 
Table 18: Distribution of Stock Traders by "Highest Educational Level and Industry/ sector where they spend the maximum amount of investments (Please choose one)"

\begin{tabular}{|l|l|l|}
\hline $\begin{array}{c}\text { Industry/Sector with } \\
\text { Maximum } \\
\text { Investment }\end{array}$ & Percentage \\
\cline { 2 - 3 } & Bachelors & Masters \\
\hline Bank & 40.22 & 35.2 \\
\hline Financial Institutions & 29.12 & 24.2 \\
\hline Pharmaceuticals & 15.2 & 10.1 \\
\hline Mutual Funds & 6.1 & 24.3 \\
\hline Other & 9.36 & 6.2 \\
\hline Total & 100 & 100 \\
\hline
\end{tabular}

Table 18; indicates that although both group prefer to investment most for bank or financial institutions, Master Degree holders shows a stronger preferences to the mutual funds.

\section{Conclusions:}

In this paper attempt was there to explore the relationship between demographic characteristics and trading behavior, and examine the difference in trading behavior of stock traders with different demographic characteristics- gender, age, and highest educational level. The results shows there is not significant differences based on these characteristics, however some of the interesting differences found are- majority of the female traders have invested less than 10 Lac whereas majority male traders' investment size is above 10 Lac, male traders' holding period is higher that female traders, female traders expect less profit and they also tolerate less loss. Differences based on age group found are-younger group hold the shares for less than a month; they also expect more profit, tolerance level increases with age but again decline for the oldest group. This paper also finds that Bachelors Degree holders' investment size higher than that of Masters Degree holders, Bachelor Degree holders prefer to sell their shares earlier than the investors with Masters Degree and Masters Degree holders tend to require less minimum target profit than Bachelor Degree holders. It is recommended that matured investors with high level of education should take the decision to invest in the stock market as they tend to focus more on the long-term that the younger and less educated group.

\section{References}

[1] Bajtelsmit, V.L., \& Bernasek, A. Why do women invest differently than men? Financial Counseling and Planning, 7, 1-10.

[2] Barber, B.M., and T.Odean, "Boys will be Boys: Gender, Overconfidence, and Common Stock Investment Performance of Individual Investors", Journal of Finance, 55, 773-806

[3] Barsky, R. B., Juster, F. T., Kimball, M. S., \& Shapiro, M. D. (1997). Preference parameters and behavioral heterogeneity: An experimental approach in the Health and Retirement Study. Quarterly Journal of Economics, 112 (2), $537-579$.

[4] Bruce, A. and Johnson, J., 1994, "Male and female betting behavior: new perspectives," Journal of Gambling Studies, 10, 183-98.

[5] Jianakoplos, N. and Bernasek, A., 1998, Are women more risk averse? Economic Inquiry 36, 620-30.

[6] Lewellen, W., Lease, R. and Schlarbaum, G., 1977, Patterns of investment strategy and behavior among individual investors, Journal of Business, 50, 296-333.

[7] Estes, R., \& Hosseini, J. (1988). The gender gap on Wall Street: An empirical analysis of confidence in investment decision making . Journal of Psychology: Interdisciplinary and Applied, 122 (6), $577-590$.

[8] Papke, L. (1998). How are participants investing their accounts in participant-directed individual account pension plans? AEA Papers and Proceedings, 88(2), 212-216. 